Archive for

Organic Chemistry

Arkivoc 2017, part iv, 273-290

\title{
Pyridinium chlorochromate chemistry. New insight into oxidation of tetrahydrofurans
}

\author{
Sabrina Zaccaria, ${ }^{\mathrm{a}}$ Nicola Borbone, ${ }^{\mathrm{b}}$ Giorgia Oliviero, ${ }^{\mathrm{b}}$ Stefano D'Errico, ${ }^{\mathrm{b}}$ and Vincenzo Piccialli*a \\ aDipartimento di Scienze Chimiche, Università degli Studi di Napoli "Federico II" \\ Via Cintia 4, 80126, Napoli, Italy \\ 'Dipartimento di Farmacia, Università degli Studi di Napoli "Federico II", \\ Via D. Montesano 49, 80131, Napoli, Italy \\ Email: vinpicci@unina.it
}

Received 02-16-2017

Accepted 05-06-2017

Published on line 05-29-2017

\section{Abstract}

A thorough investigation of the minor oxidation products of two penta-tetrahydrofuran compounds with pyridinium chlorochromate has been carried out. Isolation of ring-B oxygenated spiroketal and degradation products, including polycyclic mono- and bis-lactone compounds, supports the previously postulated involvement of cyclic enolether intermediates in the oxidation of THF and poly-THF substances with PCC. Based on the collected evidence, a new mechanistic route for the PCC-mediated oxidative cleavage of $\alpha$ hydroxy-THF compounds to $\gamma$-lactones has been postulated. The proposed mechanism well agrees with the one reported for the oxidative cleavage of 8-hydroxy-neoisocedranol oxide by $\mathrm{RuO}_{4}$, a fact that further supports our previous observation on the similar oxidizing behaviour shown by PPC and $\mathrm{RuO}_{4}$ towards $\mathrm{THF}^{-}$ containing compounds.

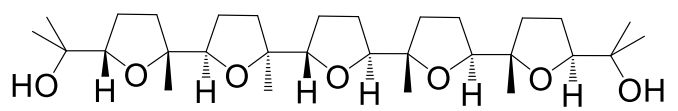

PCC/AcOH

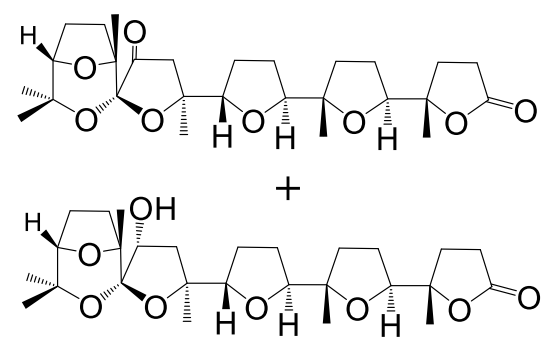

new minor spiroketal products

Keywords: Pyridinium chlorochromate, oxidation, spiroketals, mechanistic insight 


\section{Introduction}

Pyridinium chlorochromate (PCC) is a well known oxidizing reagent employed in a number of processes. ${ }^{1,2}$ Though the most popular process mediated by PCC is the oxidation of primary and secondary alcohols to aldehyde and ketones, respectively, many other functional groups undergo PCC oxidation. As a continuation of our interest in oxidative processes mediated by transition metal oxo-species ${ }^{3-11}$ as well as in the synthesis and derivatization of new THF-containing compounds, ${ }^{12-21}$ we recently focused on oxidation processes mediated by PCC. These studies led to the discovery of new interesting transformations including oxidative spiroketalization, ${ }^{22}$ oxidative cleavage of trisubstituted mono-THF compounds ${ }^{23}$ and synthesis of bis- $\alpha$ acyloxy-1,4- and 1,5-diketones from THF and THP-diols, respectively. ${ }^{24}$ During these studies evidence on some similarities about the oxidative behaviour of $\mathrm{PCC}$ and $\mathrm{RuO}_{4}$ were also recorded. In particular, we have previously reported ${ }^{22}$ that penta-THF $1^{17,20}$ (Scheme 1 ), when treated with PCC furnishes the new compounds 2-8 four of which (5-8) representative of a novel class of poly-THF spiroketals displaying antitumor activity on breast and ovarian cancer cell lines. ${ }^{22}$

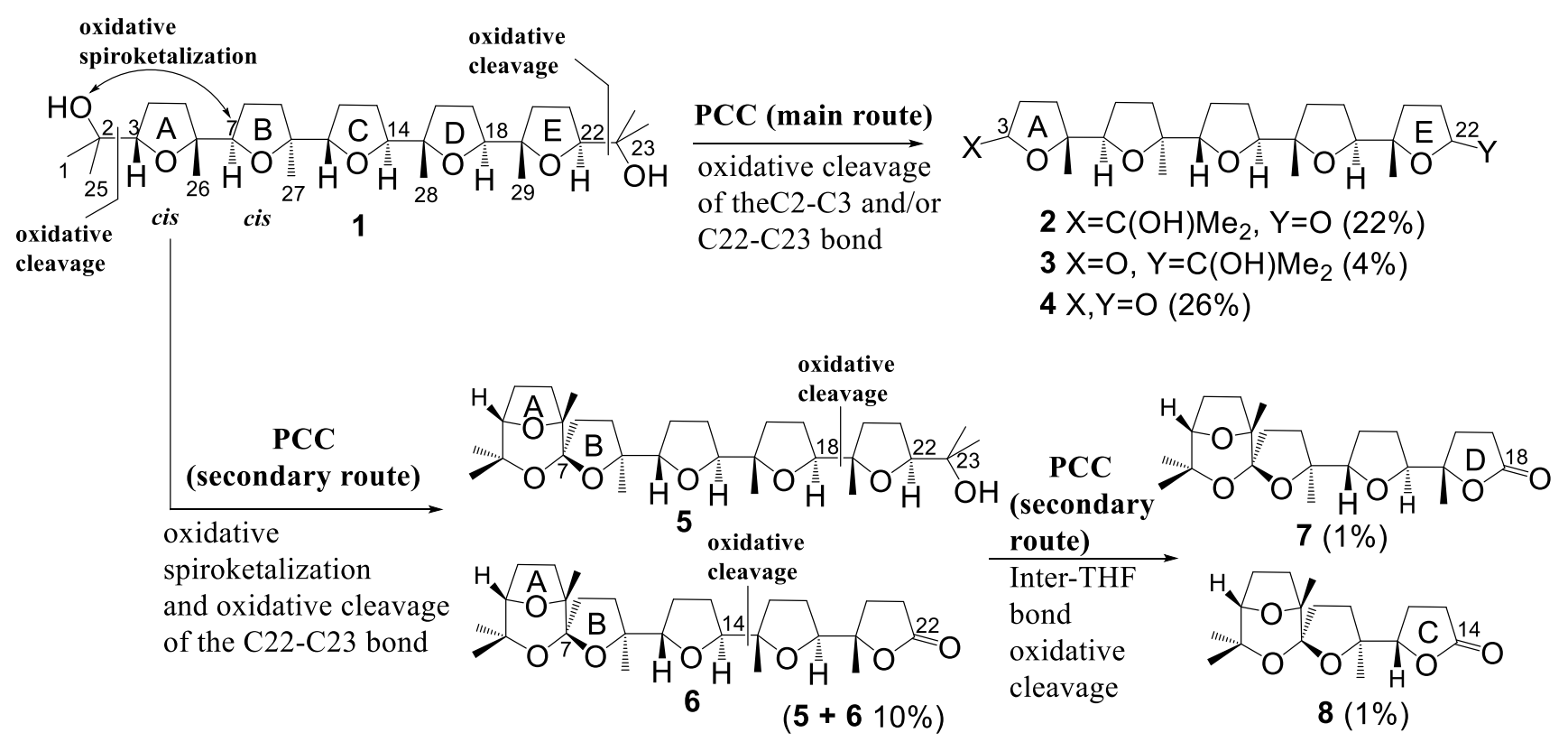

Scheme 1. A new type of spiroketal compounds obtained by PCC-mediated oxidation of penta-THF compound 1.

Inspection of the structure of these substances reveals that compound 1 undergoes three types of oxidative processes all involving the interaction of the oxidant with different THF ether methine groups:

a) The oxidative cleavage of the C2-C3 and/or C22-C23 bonds in $\mathbf{1}$ give rise to lactones $\mathbf{2}$ and $\mathbf{4}$, the main oxidation products;

b) The oxidative spiroketalization, formally involving the $\mathrm{C}(2) \mathrm{OH}$ group and the $\mathrm{C}-7$ carbon at the cis-cis bis-THF terminus of the poly-THF chain, gives rise to the spiroketal-containing compound $\mathbf{5}$, possessing the intact carbon skeleton of $\mathbf{1}$. The terminal lactone in the related spiro-compound $\mathbf{6}$, in turn, arises from the further oxidative cleavage of the $\mathrm{C} 22-\mathrm{C} 23$ bond in $\mathbf{5}$, according to the route highlighted in point a; 
c) The inter-THF C-C oxidative bond cleavage in $\mathbf{5}$ and/or $\mathbf{6}$ is responsible of the formation of the degraded, minor, spiro-compounds $\mathbf{7}$ and $\mathbf{8}$.

The transformations highlighted in points $a$ and $b$ point out the similarity of the oxidizing behaviour of PCC with the one displayed by $\mathrm{RuO}_{4}$ which catalyzes similar processes by reaction with $1 .^{13}$

The PCC-mediated conversion of $\beta$-hydroxy mono- and poly-THF compounds to $\gamma$-lactones (see for example conversion of $\mathbf{1}$ to $\mathbf{2 - 4}$ or $\mathbf{5}$ to $\mathbf{6}$ in Scheme 1 ) is a well-documented process ${ }^{14,17,25-31}$ although no definitive proof on the cleavage mechanism has been provided. On the other hand, spirocyclization leading to compounds 5-8 is a novel transformation which is attractive both from a mechanistic and applicative point of view. Therefore, we were interested to collect further evidence on these processes and, more in general, on the other oxidative routes depicted in Scheme 1. To this end, a careful analysis of the minor side-products formed during the oxidation of $\mathbf{1}$, and the corresponding dibenzoate, with PCC was undertaken. This survey allowed the identification of novel pathways working in the oxidation of differently substituted tetrahydrofurans with PCC, or allowed to confirm previously formulated mechanistic hypotheses on some PCC-mediated processes. ${ }^{22,23}$ In addition, based on the acquired evidence, we could formulate a new plausible mechanistic route on the PCC-mediated oxidative cleavage of THF rings bearing a $\alpha$ tertiary alcohol function, ${ }^{14,17,25-33}$ such as $\mathbf{1}$ and $\mathbf{2}$, to the corresponding $\gamma$-lactones, that well agrees with the mechanism proposed for the analogous process mediated by $\mathrm{RuO}_{4}$.

\section{Results and Discussion}

C-8 oxygenated spiroketals. Penta-THF 1 was synthesized from squalene according to a previously described procedure ${ }^{17}$ and its purity checked by direct and reversed-phase HPLC and high-field NMR analysis to exclude the presence of minor impurities. The oxidation of 1 in the presence of $P C C$ was carried out in $\mathrm{CH}_{2} \mathrm{Cl}_{2}$ at reflux as previously described. ${ }^{22}$ The crude reaction mixture was subjected to a careful preparative and, when required, to analytical HPLC to give the new C-8 oxygenated spiroketals $\mathbf{9}$ and $\mathbf{1 0}$ (Scheme 2) as well as some poly-THF dilactone compounds (12-14, see later Scheme 4) derived from the oxidative degradation of the carbon skeleton of $\mathbf{1}$, besides previously isolated compounds 2-8 (Scheme 1 ).

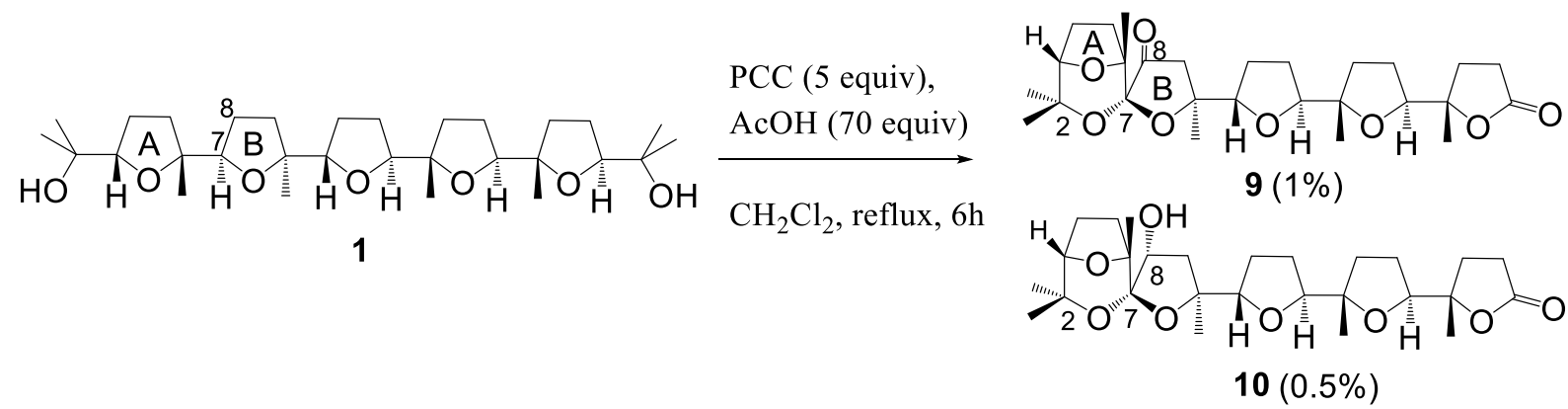

Scheme 2. Minor C-8 oxygenated spiroketal compounds obtained by PCC-mediated oxidation of 1.

Determination of the stereostructure of the 8-oxo-compound 9 was accomplished by registration of a full set of high-field 2D-NMR spectra while the structure of the corresponding C-8 alcohol 10 was inferred by chemical correlation with $\mathbf{9}$ and NMR evidence. In particular, the configuration of the C-7 spiro-centre belonging to the tricyclic spiroketal subunit in $\mathbf{9}$ was established to be the same found in related spirocompounds 5-8 (Scheme 1) through unambiguous ROESY evidence (Figure 1). 
The structural relationship between 9 and the corresponding alcohol 10 was proven by sodium borohydride reduction of 9 that gave alcohol 10 (10\%, Scheme 3), through attack of the reducing agent to the carbonyl plane from its upper face, along with the corresponding triol $\mathbf{1 1}$ (75\%), derived from the further reduction of the $\gamma$-lactone function in 9. Configuration at C-8 in $\mathbf{1 0}$ was established based on 2D-NMR studies carried out on the corresponding triol 11, available in higher amounts, having ascertained the sterostructural relationship between the two compounds by borohydride reduction of the former to the latter (Scheme 3). In particular, a significant ROESY correlation peak between Me-26 and H-8 (Figure 1) established the $\alpha$-orientation of the $\mathrm{OH}$ group in this compound and thus its cis stereostructural relationship with the oxygen bridging C-2 and C-7 in the $\mathrm{F}$ ring, a fact having important mechanistic implications, as discussed later.
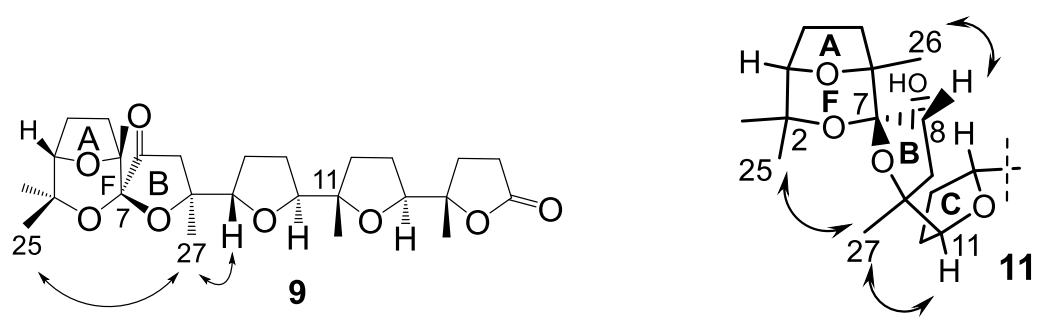

Figure 1. Some ROESY correlations of $\mathbf{9}$ (left) and a stereo-view of the spiroketal-containing portion of $\mathbf{1 0}$ showing significant ROESY correlations (right).

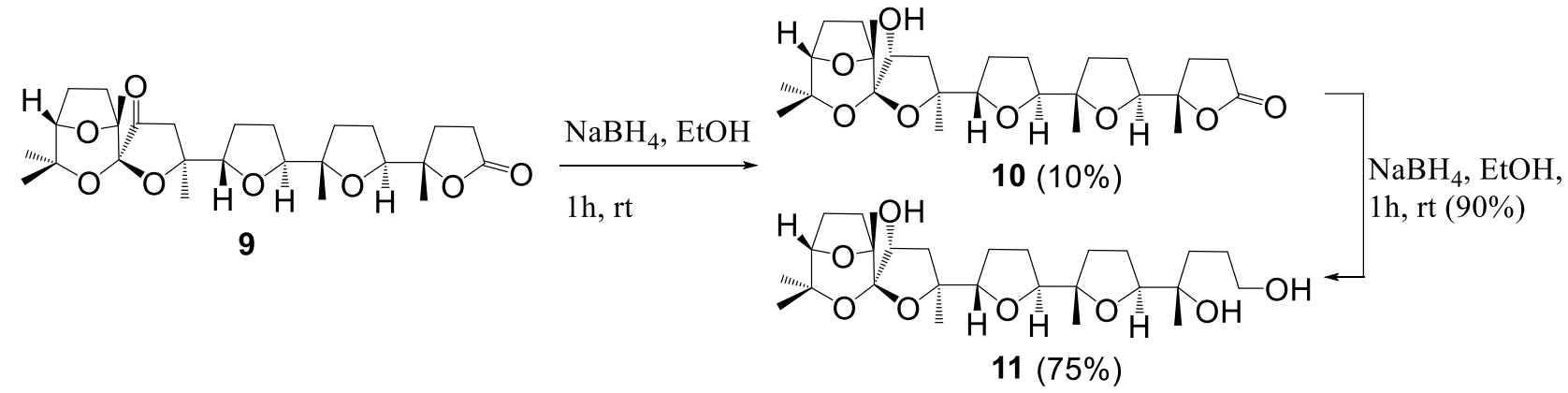

Scheme 3. Borohydride reduction of the 8-oxo-spirocompound 9.

Dilactones. Dilactones 12-14 (Scheme 4), derived from the cleavage of the poly-THF skeleton of 1 at different hydrogen-carrying ether positions, were also isolated as minor products (overall $2 \%$ yield) from the oxidation of 1 with PCC. Their stereostructures were determined by 2D-NMR studies, including ROESY experiments. The trans configuration of both the THF rings in the most abundant compound $12(1 \%)$, indicated it to originate from the oxidative cleavage of 1 at the C6-C7 bond connecting A and B THF rings accompanied by the oxidative removal of the terminal 2-hydroxypropyl moiety at the other end of the molecule (C22-C23 bond cleavage). Similarly, dilactone $13(0.5 \%)$, the threo-cis-threo-trans-threo isomer of $\mathbf{1 2}$, originated from the analogous oxidative cleavage of both the C18-C19 bond, connecting D and E THF rings, and the oxidative cleavage of the C2-C3 bond. Conflicting NMR evidence prevented assignment of the configuration of the remaining tricyclic dilactone 14 (0.5\%). Therefore, both threo-cis-threo and threo-trans-threo configurations are possible for this substance, according to two cleavage modes namely cleavage of C2-C3/C14-C15 or C10C11/C22-C23 bond pairs, respectively. 

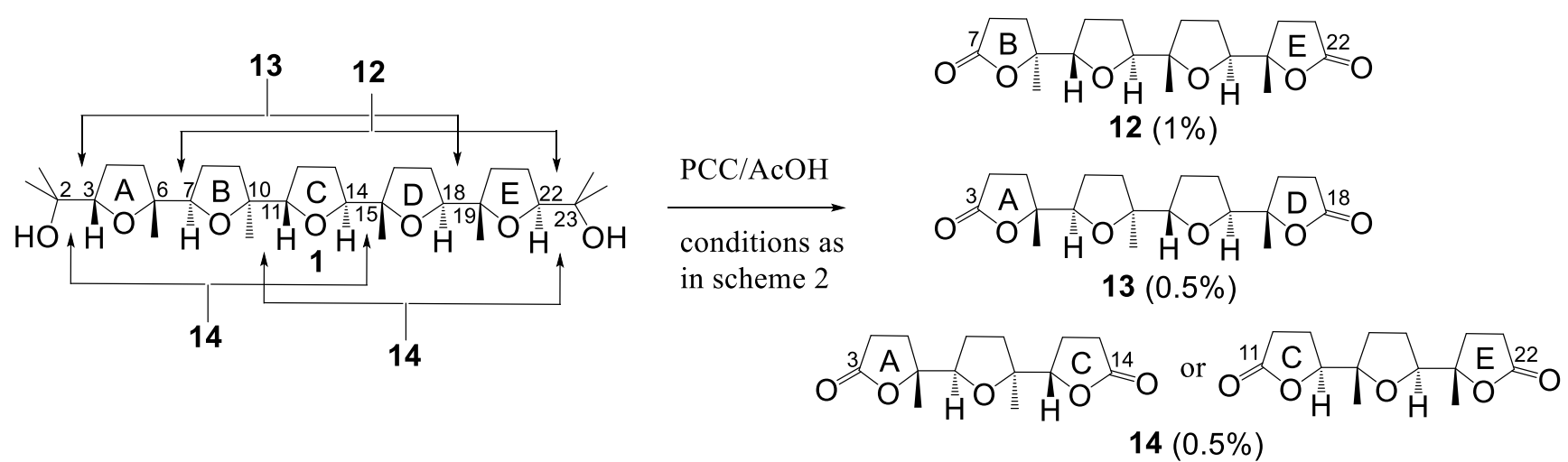

Scheme 4. Minor polycyclic dilactones from the PCC-mediated degradation of 1 and relevant cleavage patterns (see arrows).

A mechanistic rationalization for the formation of spiroketals $\mathbf{9 , 1 0}$ and dilactones $\mathbf{1 2 - 1 4}$. Isolation of the above products suggests new interesting oxidative pathways. A plausible mechanistic rationalisation for the formation of above spiroketal and dilactone substances that agrees with reported reactivity of PCC ${ }^{1,2}$ and previously developed chemistry by our own group, ${ }^{22}$ is given in schemes 5, and 7-9.

Initially, interaction of PCC with the $\mathrm{C}(2)-\mathrm{OH}$ group gives rise to chromium ester 15 (Scheme 5). Thus, the oxo-chromium appendage tethered to $\mathrm{C}-2$, in this intermediate, may attack the close-in-space $\mathrm{C} 7-\mathrm{H}$ bond, causing the closure of the spiroketal function of $\mathbf{5}$ (route a), with expulsion of a chromium species. Next, the oxidative cleavage of the $\mathrm{C} 22-\mathrm{C} 23$ bond in the latter generates the related terminal lactone 6. However, an alternative route in which a cyclic chromium diester intermediate $\mathbf{1 6}$ is formed from 15 through the [3+2] addition of its $\mathrm{O}=\mathrm{Cr}=\mathrm{O}$ portion to the $\mathrm{C} 7-\mathrm{H}$ bond (route $\mathrm{b}$ ), appears plausible.

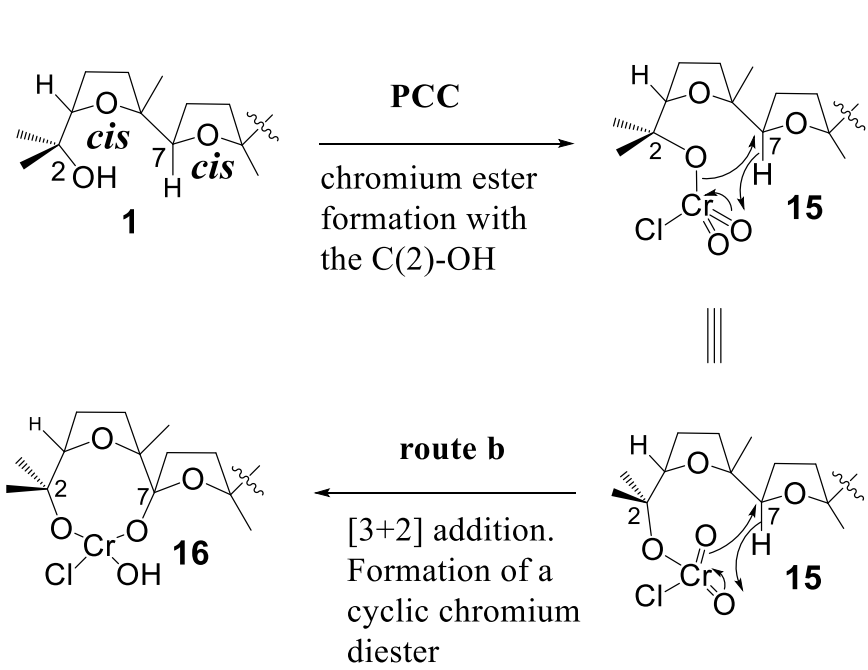

\section{route a}

[3+2] addition.

Spiroketal closure
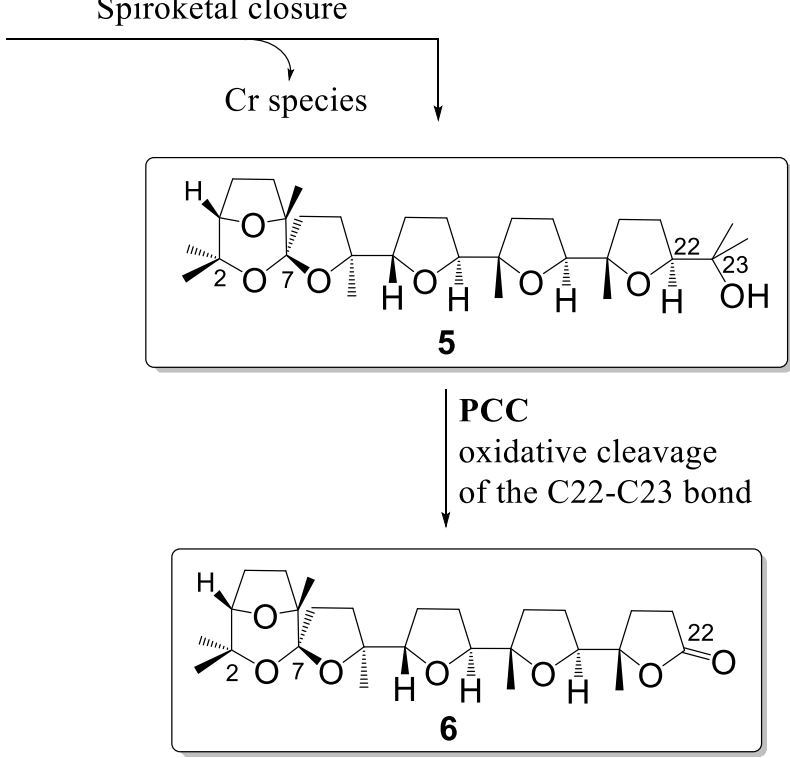

Scheme 5. A mechanistic route explaining the formation of spiroketals 5 and $\mathbf{6}$. 
The preliminary formation of chromate ester $\mathbf{1 5}$ is a reasonable assumption since there is evidence of the very rapid formation of such esters by reaction of PCC with primary, secondary and tertiary alcohols. ${ }^{34}$ On the other hand, formation of chromium diester 16 from 15 is supported by a number of previously reported evidence. Attack of transition metal oxo-species such as $\mathrm{RuO}_{4}{ }^{35-38}$ and $\mathrm{OsO}_{4}{ }^{39-41}$ to $\mathrm{C}-\mathrm{H}$ bonds of alkanes is well-known and has been suggested to proceed through [3+2] addition of a $\mathrm{C}-\mathrm{H}$ bond across an $\mathrm{O}=\mathrm{M}=\mathrm{O}$ unit through a mechanism analogous to the one now widely accepted for alkene bis-hydroxylation. In addition, it has been reported that the $\mathrm{RuO}_{4}$ oxidation of neoisocedrane oxide ${ }^{42}$ (Scheme 6), a THF-containing sesquiterpene, proceeds much in the same way we hypothesize in the transformation of 15 to 16, through the insertion of an oxoruthenium bond into the ether $\mathrm{C}-\mathrm{H}$ bond of the THF ring, successive to the formation of a ruthenate ester, aspecies analogous to $\mathbf{1 5}$. Conversion of $\mathbf{1 5}$ to $\mathbf{1 6}$ seems also plausible based on the similar oxidizing behaviour exhibited by $\mathrm{RuO}_{4}$ and PCC towards 1, recently disclosed in a study carried out in our group. $^{13,22}$

Formation of diester 16, well explains the formation of compounds $\mathbf{9 , 1 0}$ and 12, where the oxidation of the B-ring is required. In fact, 16 can be envisaged to evolve through two routes. In particular (Scheme 7), oxidative cleavage of the $\mathrm{C} 6-\mathrm{C} 7$ bond connecting $\mathrm{A}$ and $\mathrm{B}$ rings, would be responsible of the formation of intermediate mono-lactone $\mathbf{1 7}$ from which dilactone $\mathbf{1 2}$ would then be formed by cleavage of the C22-C23 bond. This route would concomitantly produce enolether 18 the C-C double bond of which would likely undergo oxidative cleavage to the dicarbonyl compound 19 , based on previous evidence on the reactivity of enolethers with PCC. ${ }^{43-45}$ Although this compound could not be detected among the oxidation products of 1 , the benzoate of 18 (see later compound 32, figure 3) has been isolated as a minor product when the dibenzoate of 1 was oxidised in the same conditions. ${ }^{23}$ A chromium diester intermediate strictly similar to 16 has been postulated in the oxidative ring fission of 2,5-dialkylfuranes with PCC to give $\alpha, \beta$-unsaturated 1,4dicarbonyl compounds. ${ }^{46}$

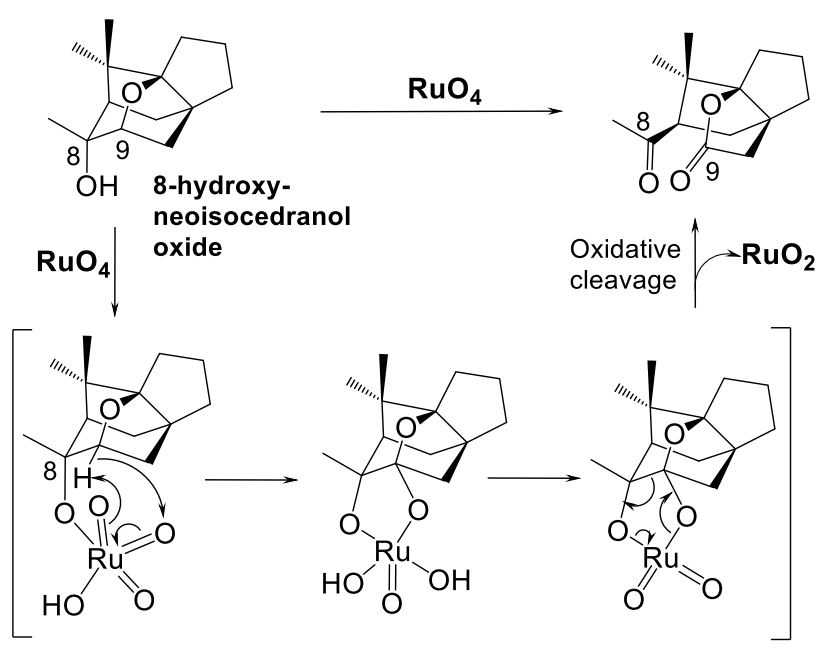

Scheme 6. Oxidative cleavage of 8-hydroxy-neoisocedranol oxide with $\mathrm{RuO}_{4}$ based on literature data [42].

Alternatively, an elimination step in $\mathbf{1 6}$ can generate the ring-B enolether intermediate $\mathbf{2 0}$ (Scheme 8), where a chromium-containing appendage is still linked to C-2 and the carbon skeleton of $\mathbf{1}$ is preserved. This step sets the basis for the formation of the spiroketal moiety of $\mathbf{1 0}$ via a successive cycloaddition step, likely a $[3+2]$ process involving the attack of the oxochromium appendage still tethered to $\mathrm{C}-2$ on the [? ${ }^{7}$ double bond of 20. The cleavage of the C22-C23 bond in the first-formed intermediate spiroketal species $\mathbf{2 1}$ then leads to 
10. The above spiroketalization step also delivers the C-8 hydroxyl group. Finally, keto-spiroketal 9 originates from the corresponding alcohol 10 by further PPC oxidation at C-8.

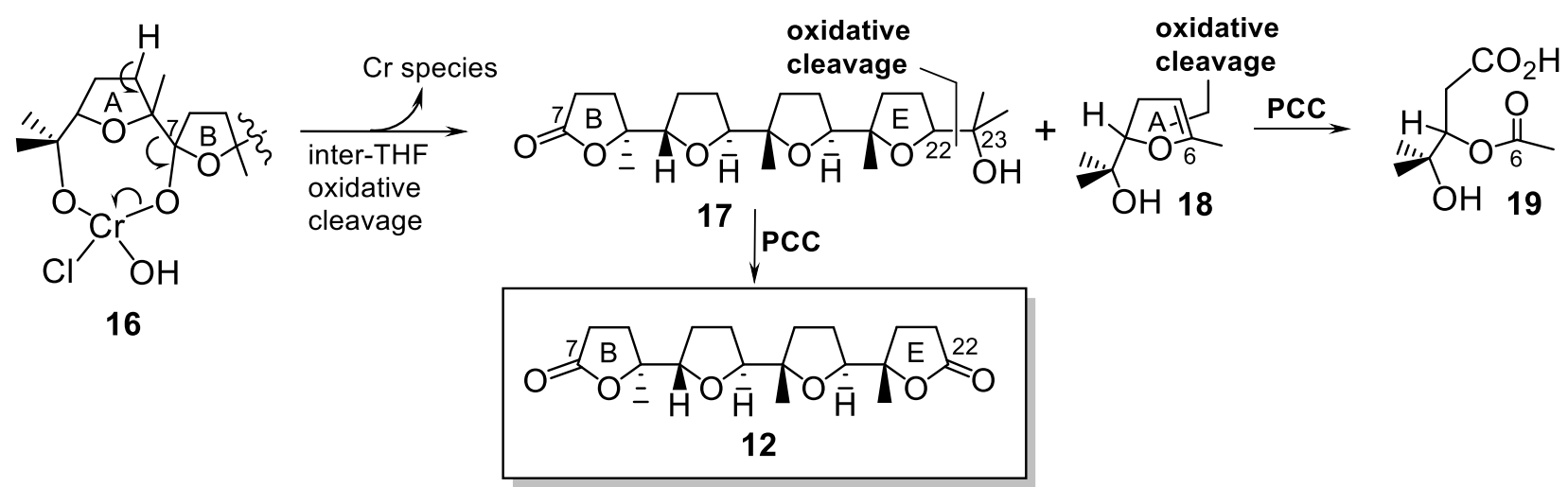

Scheme 7. A mechanistic explanation for the formation of bis-lactone 12.
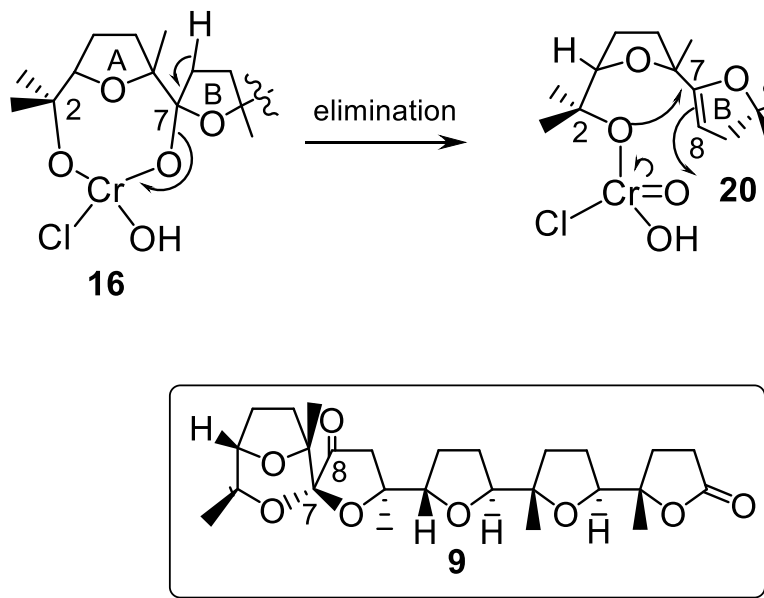

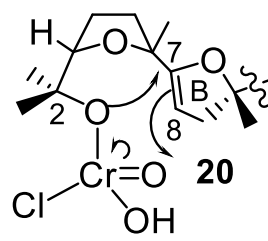

$[3+2]$

cycloaddition

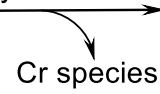

Cr species

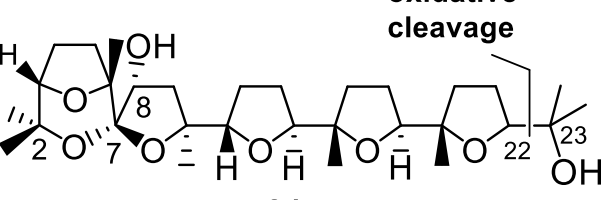

21

PCC

$\mathrm{C} 22-\mathrm{C} 23$

$\checkmark$ cleavage

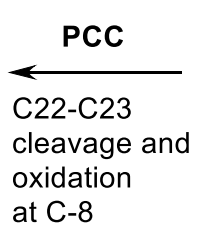
at $\mathrm{C}-8$

Scheme 8. Proposed mechanistic route for the formation of spiroketals $\mathbf{9}$ and10.

Conversion of $\mathbf{2 0}$ to $\mathbf{2 1}$ is a likely transformation because the PCC-mediated oxidative cyclization of bishomoallylic tertiary alcohols to THF-alcohols has previously been reported. ${ }^{47-49}$ It is worth noting that such a cycloaddition step also explains the observed cis relationship between the ring-F spiroketal oxygen and the C-8 hydroxyl group (Figure 1).

Our hypothesis on the spiroketalization step involved into the conversion of $\mathbf{2 0}$ to $\mathbf{1 0}$ well agrees with the McDonald et al. ${ }^{48}$ and Schlecht et al. ${ }^{49}$ mechanistic proposals. This transformation is strongly reminiscent of the oxidative spirocyclization of cyclic enolethers mediated by rhenium (VII) oxides reported by Boyce and Kennedy $\mathrm{y}^{50}$ and would represent the first example of the PCC-induced formation of a cyclic spiroketal involving an enolether double bond. It is to be noted that this transformation involves the chromium ester of a tertiary alcohol $(\mathrm{C} 2-\mathrm{OH})$ while the rhenium-mediated process is reported to induce the sole spiroketalization of primary alcohols. This transformation is certainly worth of further studies using ad hoc devised substrates.

Formation of dilactone $\mathbf{1 3}$, the cis-trans isomer of 12 , would proceed in a way strictly analogous to that leading to 12, by cleavage of C18-C19 and C2-C3 bonds, via intermediates 22 and 23 (Scheme9). However, in this case, due to the threo-trans-threo configuration of the bis-THF terminus (Figure 2), an intermolecular 
attack of PCC to $\mathrm{C} 18-\mathrm{H}$ bond is to be invoked because a $\mathrm{C} 23$-tethered oxochromium appendage and the $\mathrm{C} 18-\mathrm{H}$ bond cannot be brought near in the space, as it happens in 15 (Scheme 5), This spatial arrangement also explains why no spiroketalization is observed at this terminus but only cleavage of the C22-C23 bond to give 2 .

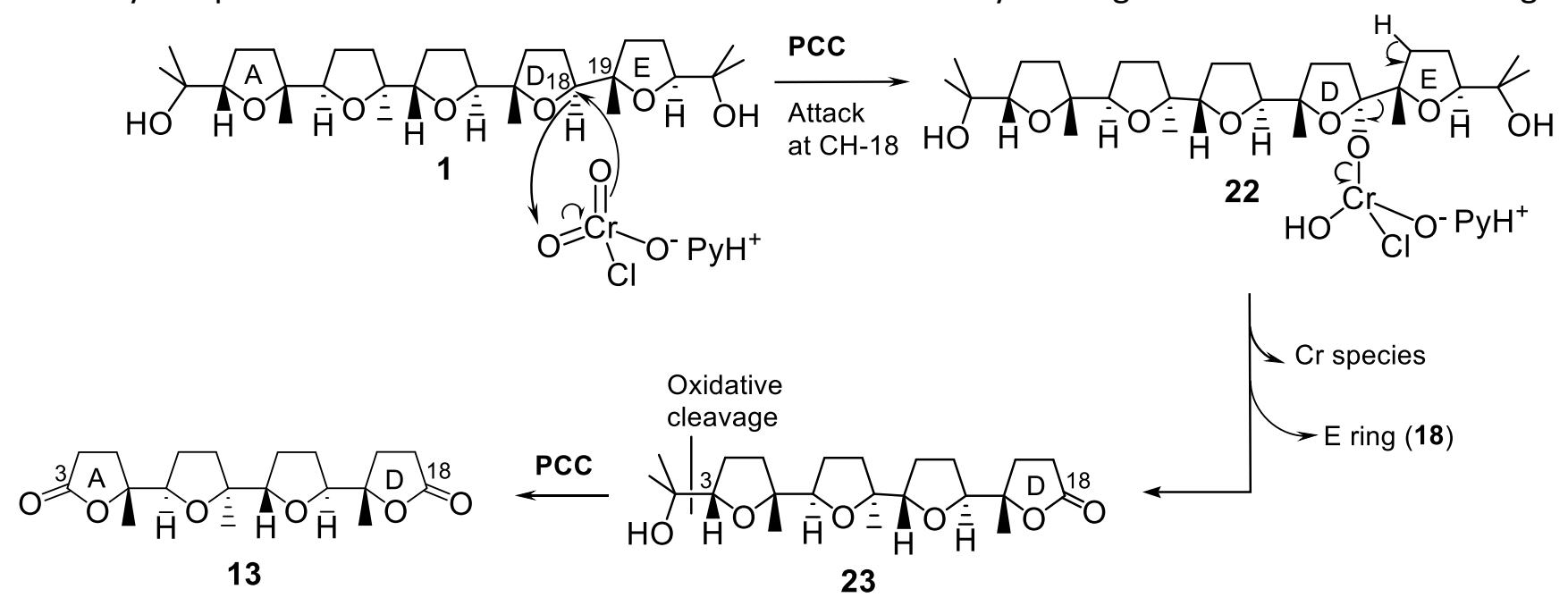

Scheme 9. Proposed route for the formation of dilactone 13.

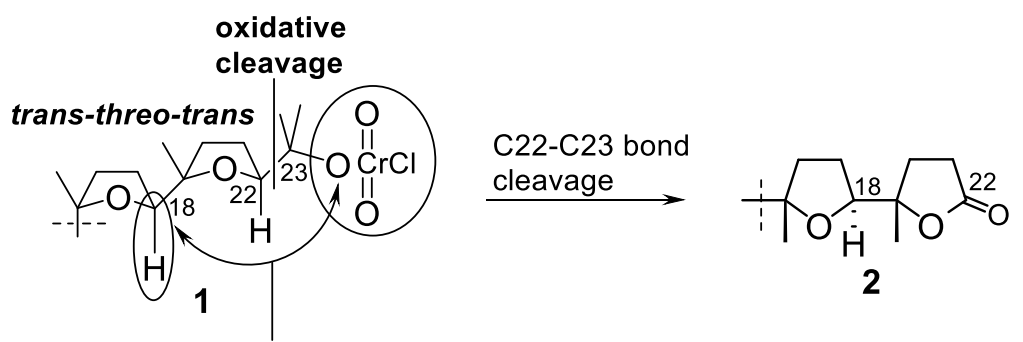

A trans relationship prevents the intra-molecular attack to $\mathrm{C} 18-\mathrm{H}$ bond: no spiroketalization, no chromium diester formation

Figure 2. Fate of the postulated chromium ester formed at the terminal trans-threo-trans bis-THF portion of 1.

Finally, formation of dilactone $\mathbf{1 4}$ from 1 is depicted in Scheme 10. It requires the cleavage of one of the bonds adjacent to the central THF ring (C10-C11 or C14-C15) to take place (the attack at the $\mathrm{C} 11-\mathrm{H}$ bond is shown in scheme 9). An inter-molecular attack of PCC is required in this case as well, to give the chromium ester intermediate $\mathbf{2 4}$ which then gives rise to bis-lactone 14 via mono-lactone $\mathbf{2 5}$. A bis-THF enolethercontaining species $\mathbf{2 6}$ would once again be produced in this step, the fate of which we were unable to follow further.

Summarising, the above results clearly established the ability of PCC to cleave inter-THF bonds in $1 .{ }^{23}$ The main oxidative routes, leading to $\gamma$-lactones $2-4,17,22$ spiro-compounds 5 and $\mathbf{6}$ as well as minor C-8 oxygenated spiro-compounds 9 and 10, and bis-lactone 12 (Schemes 1, 5, 7 and 8) proceed through the preliminary formation of chromium esters by interaction of PCC with the two hydroxyl groups of 1 . Secondary routes leading to truncated spirolactones 7 and $\mathbf{8}$ (Scheme 1), dilactones 13 (Scheme 9) and 14 (Scheme 10), likely proceed through the inter-molecular attack of PCC to suitable THF CH bonds followed by inter-THF C-C cleavage. There is evidence indicating the formation of cyclic enolethers. This also further supports our 
recently formulated hypothesis on the involvement of an enolether species in the oxidative cleavage of trisubstituted THF rings with chlorochromatoperioadate (CCP), an oxidizing agent generated by reaction of PCC and periodic acid. ${ }^{23}$
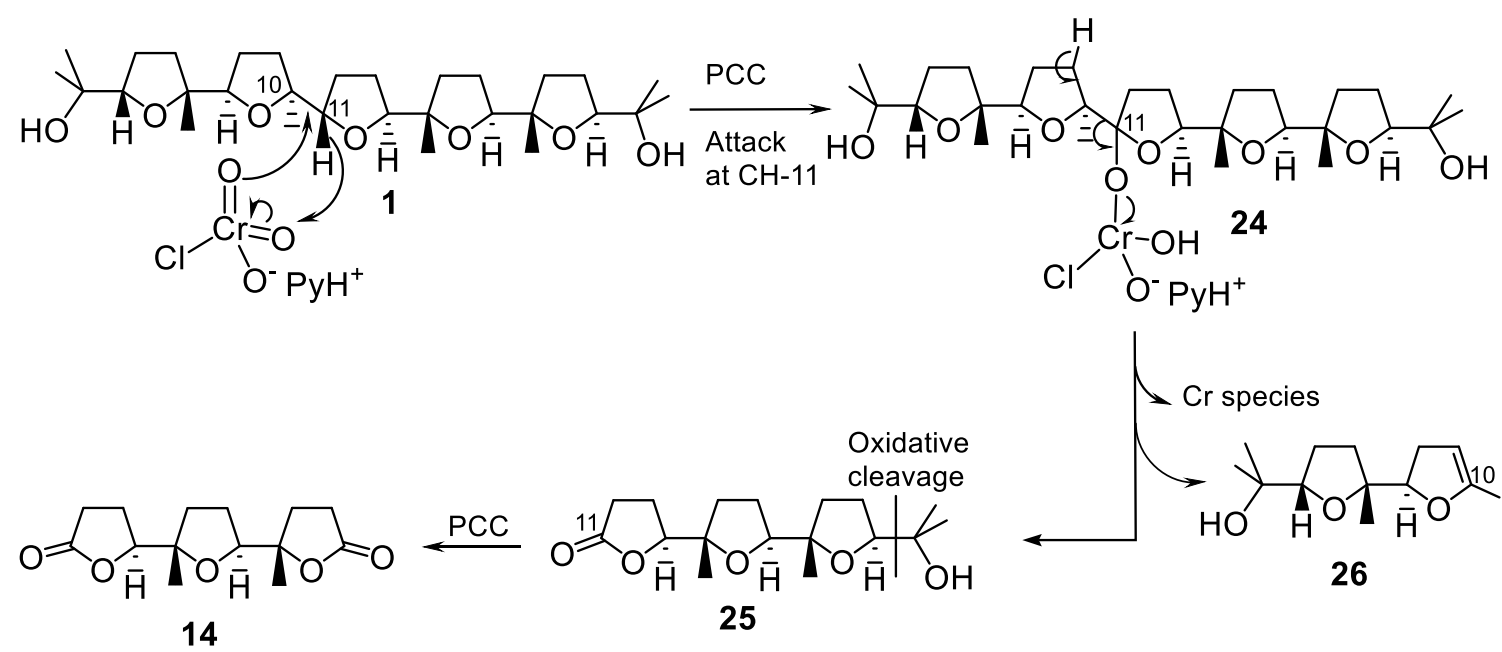

Scheme 10. Proposed mechanism for the formation of dilactone 14.

Minor oxidation products from the PCC-mediated oxidation of penta-THF dibenzoate 27. Previously, we have investigated the reactivity of compound 27, the bis-benzoate of $\mathbf{1}$ (Scheme 11), in the same oxidative conditions used for the oxidation of $1 .{ }^{23}$ Because of the absence of free C-2 and C-23 hydroxyl groups in 1, the main oxidative routes giving terminal lactones $\mathbf{2 - 4}$, as well as spirocompounds 5-8 were depressed and the intermolecular attack of PCC to the internal THF rings in $\mathbf{1}$ was enhanced. This resulted in the formation of compounds $\mathbf{2 8}$ and $\mathbf{2 9}$ as the major products. We hypothesized that they could originate by the oxidative cleavage of ring-B or $\mathrm{D}$ enolethers. ${ }^{23}$ In addition, ketol 30, embodying a ring-B oxygenated moiety, lactone $\mathbf{3 1}$, lacking one of the terminal rings of $\mathbf{2 7}$, and fragment $\mathbf{3 2}$, were also isolated as minor products. Formation of these compounds could be rationalised through involvement of ring-B or D enolethers, as well. Isolation of compounds 28-32 suggested the preferential attack of PCC to $B$ and D rings in 27 . A reinvestigation of the oxidation of $\mathbf{2 7}$ with $\mathrm{PCC}_{\text {, }}$, in the previously tested conditions, has now led to the identification of further four minor products originating from the attack of the oxidant to the central C THF ring. Their formation has been explained through mechanistic paths in line with those formulated for all the other reaction products. In particular, the two isomeric, small-sized, lactones $\mathbf{3 3}$ and $\mathbf{3 4}$ (major isomer 4\%; minor isomer 2\%) and the two isomeric unsaturated aldehydes 35 and 36 (1\% each), were isolated. 


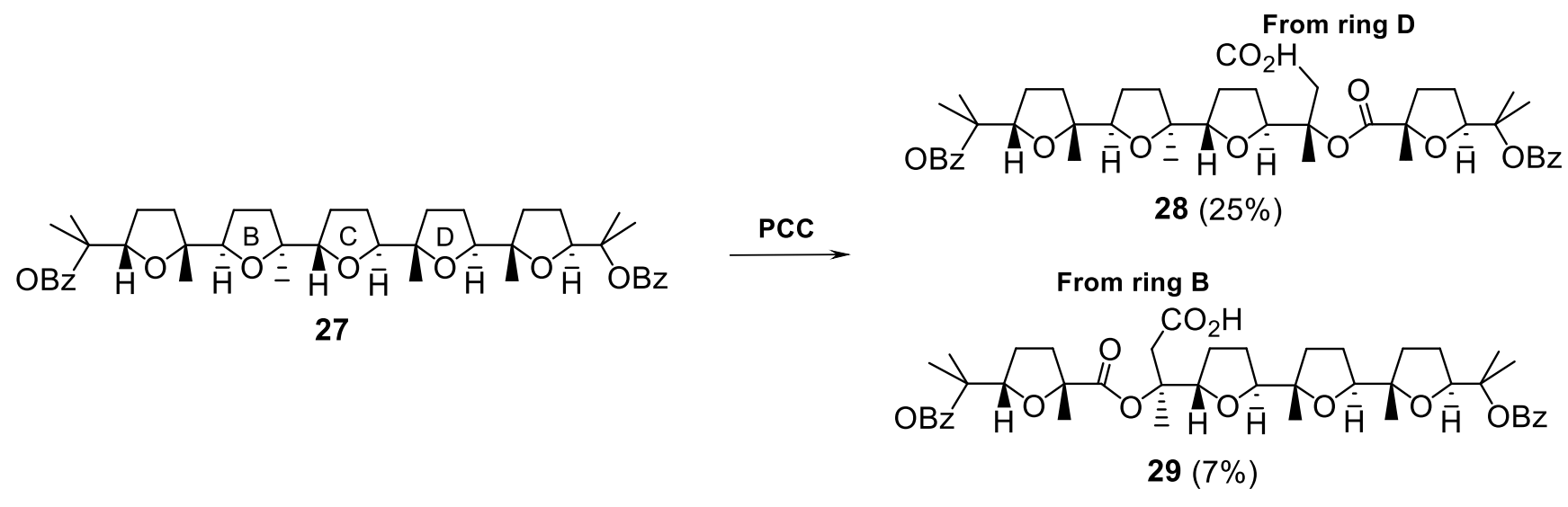

Scheme 11. Major products from the oxidation of penta-THF dibenzoate 31.
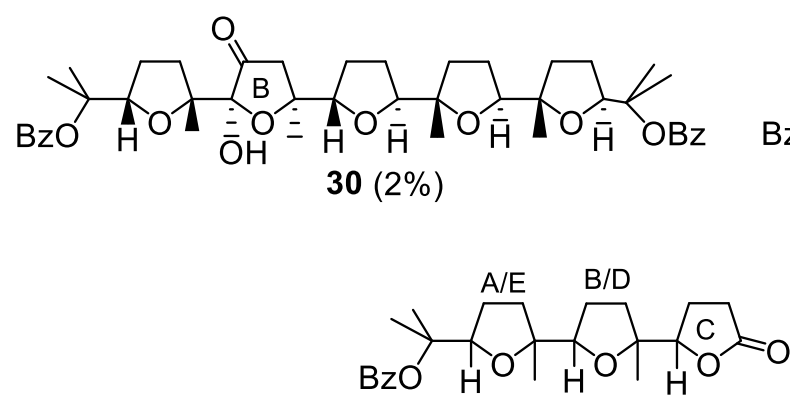

33 (major isomer $4 \%$ )

34 (minor isomer $2 \%$ )<smiles>CC(C)(OC(=O)c1ccccc1)C1CCC(C)(C2CCC(C3CCC(C4CCC(C(C)(C)[C@H]5CCC(=O)O5)O4)O3)O2)O1</smiles>

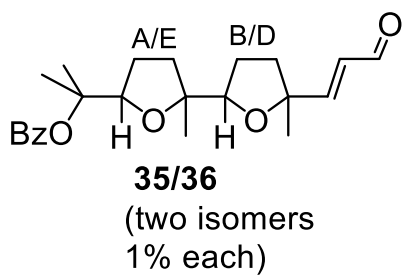<smiles>CC(=O)OC(CC(=O)O)(CC(C)(C)C)C(C)(C)C</smiles>

$32(1 \%)$

Figure 3. Minor products from the oxidation of penta-THF dibenzoate $\mathbf{2 3}$ with PCC.

Formation of degraded compounds 33-36 can be rationalized through attack of PCC to $\mathrm{C} 11-\mathrm{H}$ or $\mathrm{C} 14-\mathrm{H}$ in the central THF ring (Scheme 12), according to mechanistic routes above depicted for the oxidation of 1 (Schemes 9 and 10). When reasoning for the attack at $\mathrm{C} 14-\mathrm{H}$, lactones $\mathbf{3 3}$ and $\mathbf{3 4}$ would derive from the monoester intermediate 37 by oxidative cleavage of $\mathrm{C} 14-\mathrm{C} 15$ bond (route a). An alternative path (route b) would lead to the ring- $C$ enolether 38 , by elimination of a chromium species. Oxidative cleavage of the enolether double bond in the latter, followed by the further elimination of the rings D/E-containing portion of the molecule, would give rise to the conjugated aldehydes $\mathbf{3 5}$ and $\mathbf{3 6 .}$ 


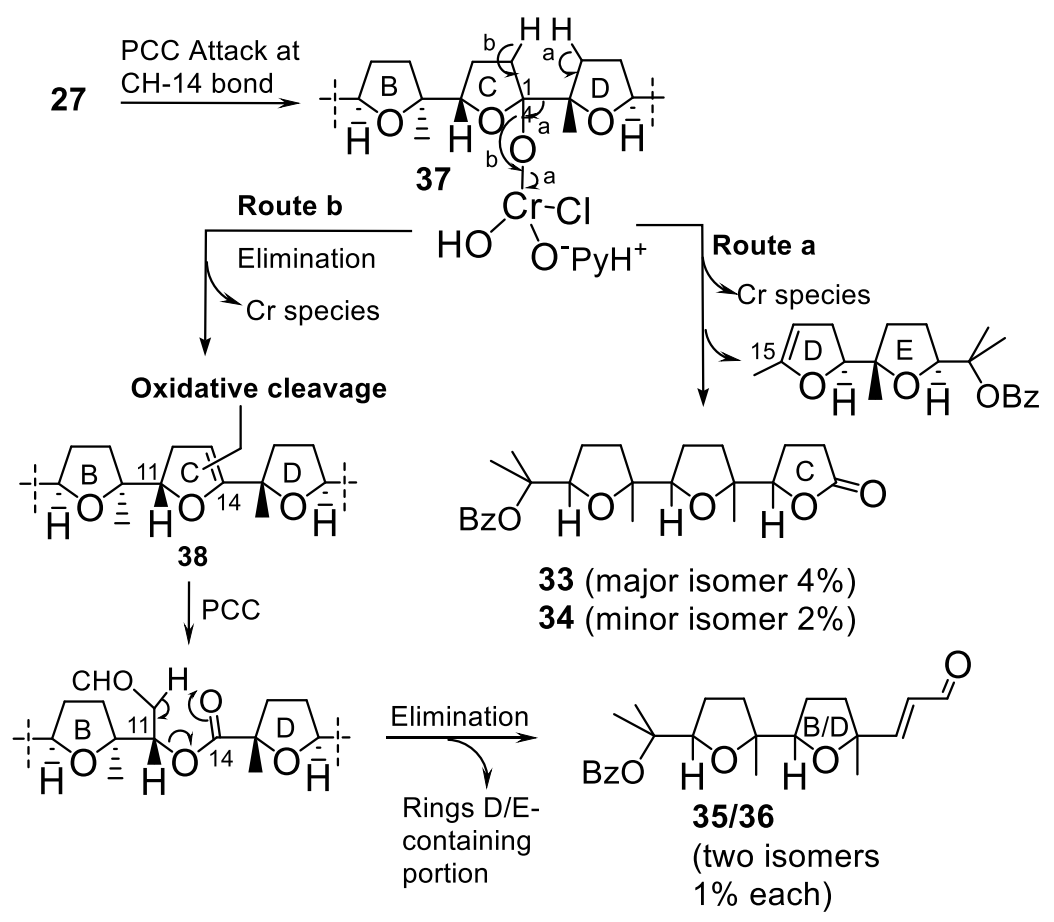

Scheme 12. Formation of 33-36 from 27.

A new proposed mechanism for the oxidative cleavage of $\alpha$-hydroxy-THF compounds. Conversion of 1 to $2-$ 4. The PCC-mediated oxidative cleavage of $\alpha$-hydroxy mono- and poly-THF compounds to $\gamma$-lactones (see for example conversion of $\mathbf{1}$ to $\mathbf{2 - 4}$ or $\mathbf{5}$ to $\mathbf{6}$ in Scheme 1) is a well-documented process ${ }^{25-29}$ interesting both from a mechanistic and applicative point of view. No definitive evidence on the real path of this transformation has been provided to date although plausible speculative reasoning have been put forward. ${ }^{17,25-29}$ In the light of the above collected evidence a comment to this transformation, with reference to THF bearing $\alpha$-tertiary alcoholic moieties, seems appropriate. When reasoning for example for the transformation of $\mathbf{1}$ to $\mathbf{3}$ (Scheme 1), a summary of the reported routes, explaining the oxidative cleavage of the C2-C3 bond, is shown in Scheme 13.

In particular, the great part of the reported hypotheses supposes a preliminary coordination of PCC to the alcohol group $\alpha$ to the THF ring. In accord with the route proposed by Stark et al. ${ }^{25}$ for the strictly related oxidative cleavage of THF and THP alcohols to $\gamma$ - and $\delta$-lactones, the C- 2 tethered oxochromium appendage in the first-formed species $\mathbf{1 5}$ may attack the C-3 carbon though route a, with formation of a C-3 chromium ester intermediate $\mathbf{3 9}$ that, as such or in a different oxidation state, would generate the lactone function in $\mathbf{3}$. Alternatively, a cation species $\mathbf{4 0} \mathbf{1 7}^{17,25}$ could be formed (route b) that is then further oxidised by PCC to give $\mathbf{3}$. Another reported route (route $c)^{28}$ supposes the involvement of an enolether species such as $\mathbf{4 1}$, formed by dehydration, that is then cleaved by PCC. However, such a type of substance could not be detected among the reaction products, as the authors pointed out. ${ }^{28}$ In line with our reasoning on the conversion of 15 to 16 shown in Scheme 5, we believe that a fourth plausible path (Scheme 14) can be proposed where the C3-H bond is attacked by the close-in-space $\mathrm{C}-2$ tethered oxidant, to give the cyclic chromium diester $\mathbf{3 0}$. Successive oxidative fragmentation of this intermediate, would proceed in the usual manner with expulsion of acetone, generating the lactone function of 3 . Note that this route would compete with the one where the $\mathrm{C7}-\mathrm{H}$ is attacked by the same C-2 oxochromium portion to give 16, as shown in Scheme 5 . Cyclic esters such as 42 are thought to be involved into the oxidative cleavage of alkenes or vicinal diols with related oxo-species $\mathrm{RuO}_{4}$, 
$\mathrm{OsO}_{4}, \mathrm{RuO}_{4}^{-}$and $\mathrm{MnO}_{4}^{-}$. Importantly, our path is strictly similar to the proposed route for the oxidative cleavage observed for 8-hydroxy-neoisocedranol oxide with $\mathrm{RuO}_{4}$ shown above in Scheme 6, ${ }^{42,3,13}$, which we also postulated to work in the ruthenium tetroxide catalyzed oxidative cleavage of strictly related poly-THF spiroketal compounds. ${ }^{13}$ On this ground it seems conceivable that this route could also work in the oxidative cleavage of related $\alpha$-hydroxy-THF substances studied by others. ${ }^{25-29}$

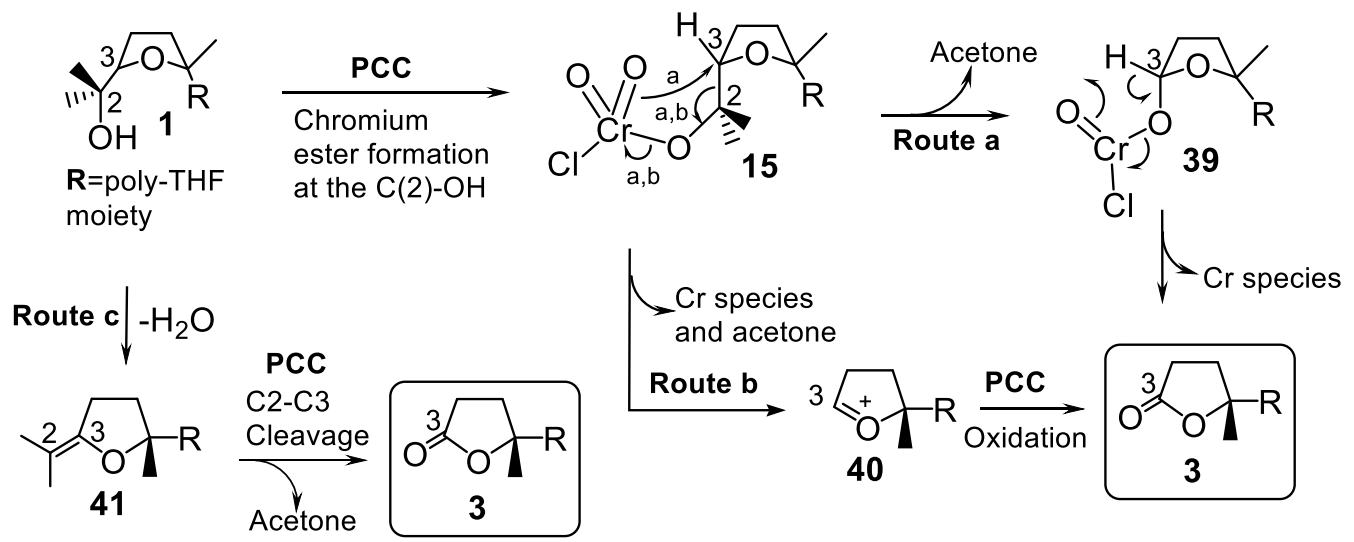

Scheme 13. Oxidative cleavage of the $\alpha$-hydroxy-THF portion of 1 according to previously formulated mechanistic hypotheses.

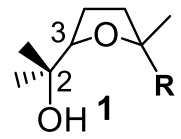

$\mathbf{R}=$ poly $-\mathrm{THF}$ moiety

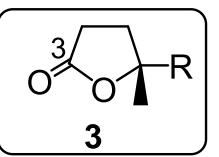

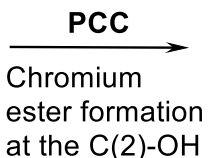

at the $\mathrm{C}(2)-\mathrm{OH}$

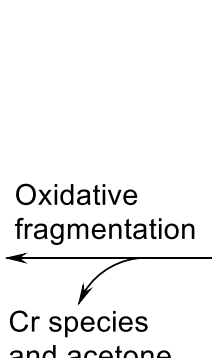

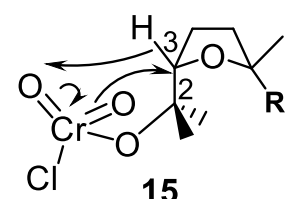

15

Chromium diester formation

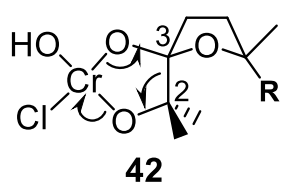

Scheme 14. Our proposed route for the oxidative cleavage of the $\alpha$-hydroxy-THF portion in 1.

\section{Conclusions}

The data collected in the present study expand our knowledge on the oxidative behaviour of PCC with poly-THF compounds under classical conditions and may help to understand the reactivity of PCC with simpler ether compounds. Penta-THF 1 revealed itself as a good model compound to study the action of PCC on adjacently linked poly-THF compounds. Novel oxidative pathways leading to degradation, or oxidative modification, of the poly-THF skeleton, with formation of new types of poly-THF compounds, have been disclosed. Plausible hypotheses, consistent with the known reactivity of $\mathrm{PCC}$, have been presented to explain the formation of all isolated substances. In particular, attack of the oxidant at the various THF C-H bonds, either in an intra- or inter-molecular way, is thought to be the first event, which 
leads to formation of a chromium ester intermediate. The main products originate from the first-formed chromium ester species with the alcohol functions in 1. Inter-THF bond cleavage, to give small-sized dilactones, takes place in a little extent by intra-molecular attack of PCC to THF rings. Isolation of minor C-8 oxygenated spiroketal compounds strongly suggests that a cyclic ring-B enolether is involved in their formation. We believe that further experimental work on the chromium-mediated spiroketalization of cyclic enolethers, including $\alpha$-tethered tertiary alcohol portions in their structure, is certainly desirable. Oxidation of dibenzoate $\mathbf{2 7}$ led to degraded compounds the formation of which is explained through the intervention of ring- $C$ enolethers in this case as well. Additional support to the previously observed similarity of the chemical oxidative behaviour of PCC and $\mathrm{RuO}_{4}$ towards THF-containing substances, ${ }^{13}$ has been provided. Further clarification of this issue could come from theoretical studies.

\section{Experimental Section}

General. All reagents were purchased at the highest commercial quality and used without further purification. Reactions were monitored by thin-layer chromatography carried out on precoated silica gel plates (Merck 60, $\mathrm{F}_{254}, 0.25 \mathrm{~mm}$ thick). Merck silica gel (Kieselgel 40, particle size 0.063-0.200 mm) was used for column chromatography. $\mathrm{Na}_{2} \mathrm{SO}_{4}$ was used as a drying agent for aqueous work-up. HPLC separations were carried out on a Varian 2510 apparatus equipped with a Waters R403 dual cell differential refractometer using Phenomenex $250 \times 10 \mathrm{~mm}$ and $250 \times 4.6 \mathrm{~mm}$ (both $5 \mu$ ) and LiChrosorb RP-18 $250 \times 4.0 \mathrm{~mm}$ columns. NMR experiments were performed on Varian Unity Inova 700, Varian Unity-Inova 500, Varian Mercury Plus 400, Gemini 200 spectrometers in $\mathrm{CDCl}_{3}$. Proton chemical shifts were referenced to the residual $\mathrm{CHCl}_{3}$ signal $(7.26$ ppm). ${ }^{13} \mathrm{C}-\mathrm{NMR}$ chemical shifts were referenced to the solvent $(77.0 \mathrm{ppm})$. $J$ values are given in $\mathrm{Hz}$. Abbreviations for signal coupling are as follows: $s$, singlet; $d$, doublet; $t$, triplet; $q$, quartet; $m$, multiplet. IR spectra were recorded on a Jasco FT-IR 430 spectrophotometer. The High Resolution MS were recorded on a Bruker APEX II FT-ICR mass spectrometer using electron spray ionization (ESI) technique. For all the reported products the numbering previously given ${ }^{17}$ for the penta-THF 1 is used.

Penta-THF 1 and its oxidation with PCC/AcOH. Isolation of minor products 9, 10 and 12-14. Penta-THF 1 was synthesized as previously described. ${ }^{17}$ To a solution of 1 (332 mg, $0.63 \mathrm{mmol}$ ) in $\mathrm{CH}_{2} \mathrm{Cl}_{2}(5 \mathrm{~mL}$ ) was added PCC (5 equiv. $3.16 \mathrm{mmol}, 682 \mathrm{mg}$ ) and $\mathrm{AcOH}$ (70 equiv., $2.5 \mathrm{~mL}$ ) and the resulting heterogeneous mixture was stirred at room temperature for $6 \mathrm{~h}$. A saturated aqueous $\mathrm{NaHCO}_{3}$ solution was added and the mixture was extracted with $\mathrm{CH}_{2} \mathrm{Cl}_{2}$. The combined extracts were dried and evaporated in vacuo to give a yellow oil. Filtration on a silica gel pad (eluent $\mathrm{CHCl}_{3}-\mathrm{MeOH}, 9: 1$ ) afforded a colourless oil (310 mg) that was separated by HPLC (250x10 mm column; flow: $2.5 \mathrm{~mL} / \mathrm{min}$; eluent: hexane-EtOAc, 65:35) to give spirolactone 7 (2.5 mg, $1 \%$, $t_{\mathrm{R}} 13.5 \mathrm{~min}$ ), spirolactone 8 (1.9 mg, 1\%, $t_{\mathrm{R}} 18.5 \mathrm{~min}$ ), spiroketone 9 (3.1 mg, 1\%, $t_{\mathrm{R}} 15.0 \mathrm{~min}$ ), spiroalcohol 10 $\left(1.6 \mathrm{mg}, 0.5 \%, t_{\mathrm{R}} 17.5 \mathrm{~min}\right)$ and bis-lactone $12\left(2.1 \mathrm{mg}, 1 \%, t_{\mathrm{R}} 41.0 \mathrm{~min}\right)$. The fraction eluted in the range 26-38 min contained a mixture of bis-lactones 13 and 14. A further HPLC run of this fraction (eluent: hexane-EtOAc, 3:7) gave ca. $80 \%$ pure $13\left(t_{R} 17.0 \mathrm{~min}\right)$ and $14\left(t_{\mathrm{R}} 15.0 \mathrm{~min}\right)$. Final purification of these substances was carried out by reversed-phase HPLC ( $250 \times 4.6 \mathrm{~mm}$ column; flow: $1.0 \mathrm{~mL} / \mathrm{min}$; 13 : eluent $\mathrm{CH}_{3} \mathrm{CN} / \mathrm{H}_{2} \mathrm{O}, 6: 4, t_{\mathrm{R}} 4.5 \mathrm{~min}$; 14: eluent $\left.\mathrm{CH}_{3} \mathrm{CN} / \mathrm{H}_{2} \mathrm{O}, 7: 3, t_{\mathrm{R}} 3.0 \mathrm{~min}\right)$ to give $13(1.0 \mathrm{mg}, 0.5 \%)$ and $14(0.8 \mathrm{mg}, 0.5 \%)$.

9. Amorphous solid; IR (neat) $v_{\max } 1763,1699,1045 \mathrm{~cm}^{-1} .{ }^{1} \mathrm{H}-\mathrm{NMR}\left(500 \mathrm{MHz}, \mathrm{CDCl}_{3}\right.$ ) selected values $\delta 3.91$ $\left(1 \mathrm{H}, \mathrm{d}, J\right.$ 7.0), 3.87-3.79 (3H, m), $2.88(1 \mathrm{H}, \mathrm{ddd}, J 13.0,9.7,5.4), 2.86\left(1 \mathrm{H}, \mathrm{d}, J\right.$ 17.6, $\left.\mathrm{H}_{\mathrm{a}}-9\right), 2.76(1 \mathrm{H}, \mathrm{ddd}, J 17.6$, 10.6, 9.4, $\left.\mathrm{H}_{\mathrm{a}}-21\right), 2.45\left(1 \mathrm{H}, \mathrm{ddd}, J\right.$ 17.6, 10.3, 3.3, $\left.\mathrm{H}_{\mathrm{b}}-9\right), 2.36\left(1 \mathrm{H}, \mathrm{d}, J \mathrm{7.6}, \mathrm{H}_{\mathrm{b}}-9\right) 2.35$ (1H, m, partially 
overlapped to the $\mathrm{H}_{\mathrm{b}}-9$ signal), 2.14-2.00 (3H, overlapped multiplets), $2.00-1.82$ (7H, overlapped multiplets), $1.60(1 \mathrm{H}, \mathrm{ddd}, J 12.1,7.8,4.8), 1.40(1 \mathrm{H}, \mathrm{ddd}, J 12.8,12.8,4.2), 1.52,1.35,1.32,1.21,1.06,1.04$ (3H each, s's, 6xMe); ${ }^{13} \mathrm{C}-\mathrm{NMR}\left(125 \mathrm{MHz}, \mathrm{CDCl}_{3}\right) \delta 208.9,178.0,100.9,86.3,85.8,85.3,84.9,83.7,82.6,81.3,78.7,76.0$, $44.9,34.4,32.4,30.3,30.0,27.6,26.7,26.5,26.2,26.1,25.6,25.0,23.9,23.4,21.2$; HRMS (ESI) $\mathrm{m} / \mathrm{z}$ calcd for $\mathrm{C}_{27} \mathrm{H}_{40} \mathrm{NaO}_{8}[\mathrm{M}+\mathrm{Na}]^{+}$515.2621, found 515.2630.

10. Amorphous solid; IR (neat) $v_{\max } 3398(\mathrm{br}), 1763 \mathrm{~cm}^{-1}$; ${ }^{1} \mathrm{H}-\mathrm{NMR}\left(300 \mathrm{MHz}, \mathrm{CDCl}_{3}\right)$ selected values $\delta 4.09(1 \mathrm{H}$, $\mathrm{dt}, J$ 11.1, 8.7, 8.7), $3.90(1 \mathrm{H}, \mathrm{d}, J$ 6.9), $3.83(1 \mathrm{H}, \mathrm{dd}, J$ 7.3, 7.3$), 3.75(1 \mathrm{H}, \mathrm{m}) 3.57(1 \mathrm{H}, \mathrm{m}), 2.77(1 \mathrm{H}, \mathrm{dt}, J 16.9$, 9.3, 9.3), 1.54, 1.33, 1.30, 1.26, 1.09, 1.02 (3H each, s's, 6xMe); HRMS (ESI) $m / z$ calcd for $\mathrm{C}_{27} \mathrm{H}_{42} \mathrm{NaO}_{8}[\mathrm{M}+\mathrm{Na}]^{+}$ 517.2777 , found 517.2789.

12. Oil; IR (neat) $v_{\max } 1769 \mathrm{~cm}^{-1} ;{ }^{1} \mathrm{H}-\mathrm{NMR}\left(400 \mathrm{MHz}, \mathrm{CDCl}_{3}\right) \delta 3.88-3.81(2 \mathrm{H}, \mathrm{m}), 3.79(1 \mathrm{H}, \mathrm{dd}, J$ 9.6, 5.5), 2.83$2.70(2 \mathrm{H}, \mathrm{m}), 2.52-2.32(4 \mathrm{H}$, overlapped multiplets), 2.09-1.76 (9H, overlapped multiplets), $1.68-1.60(1 \mathrm{H}, \mathrm{m})$, $1.33(6 \mathrm{H}, \mathrm{s}, 2 \times \mathrm{Me}), 1.05(3 \mathrm{H}, \mathrm{s}, \mathrm{Me}) ;{ }^{13} \mathrm{C}-\mathrm{NMR}\left(100 \mathrm{MHz}, \mathrm{CDCl}_{3}\right) \delta 177.9,177.6,86.3,86.1,85.74,85.68,85.3$, 84.7, 34.5, 32.6, 32.3, 29.9, 29.8, 27.2, 26.9, 26.5, 23.9, 23.5, 23.0; HRMS (ESI) $\mathrm{m} / z$ calcd for $\mathrm{C}_{19} \mathrm{H}_{29} \mathrm{O}_{6}[\mathrm{M}+\mathrm{H}]^{+}$ 353.1964, found 353.1948 .

13. Oil; IR (neat) $\left.v_{\max } 1769 \mathrm{~cm}^{-1} ;{ }^{1} \mathrm{H}-\mathrm{NMR} 400 \mathrm{MHz}, \mathrm{CDCl}_{3}\right)$ selected values $\delta 3.94(1 \mathrm{H}, \mathrm{dd}, J \mathrm{~J} .4,7.4), 3.84(1 \mathrm{H}$, dd, J 7.5, 7.5), $3.72(1 \mathrm{H}, \mathrm{dd}, J$ 9.7, 4.4), 2.82-2.67 (2H, m), $2.54(1 \mathrm{H}, \mathrm{bt}, J 12.7), 2.48-2.37$ (3H, overlapped multiplets), $2.10(1 \mathrm{H}, \mathrm{m}), 1.35,1.31,1.09$ (3H each, s's, $3 \times \mathrm{Me}) ;{ }^{13} \mathrm{C}-\mathrm{NMR}\left(100 \mathrm{MHz}, \mathrm{CDCl}_{3}\right) \delta 178.1,177.7$, 86.7, 85.7, 84.89, 84.81, 84.0, 83.7, 34.8, 32.6, 32.2, 30.04, 30.00, 27.1, 26.7, 26.6, 24.6, 24.0, 23.3; HRMS (ESI) $\mathrm{m} / \mathrm{z}$ calcd for $\mathrm{C}_{19} \mathrm{H}_{29} \mathrm{O}_{6}[\mathrm{M}+\mathrm{H}]^{+} 353.1964$, found 353.1951 .

14. Oil; IR (neat) $v_{\max } 1762 \mathrm{~cm}^{-1} ;{ }^{1} \mathrm{H}-\mathrm{NMR}\left(200 \mathrm{MHz}, \mathrm{CDCl}_{3}\right) \delta 4.36(1 \mathrm{H}, \mathrm{dd}, J 6.8,6.8), 3.90(1 \mathrm{H}, \mathrm{dd}, J$ 7.8, 7.8), 2.74-1.87 (11H, overlapped multiplets), 1.80-1.72 (1H, m), $1.32(3 \mathrm{H}, \mathrm{s}, \mathrm{Me}), 1.15(3 \mathrm{H}, \mathrm{s}, \mathrm{Me}) ;{ }^{13} \mathrm{C}-\mathrm{NMR}(100$ $\left.\mathrm{MHz}, \mathrm{CDCl}_{3}\right) \delta 177.7,177.3,86.9,85.8,85.3,84.5,34.0,32.4,29.9,28.6,26.1,23.8,23.0,22.8 ; \mathrm{HRMS}$ (ESI) $\mathrm{m} / \mathrm{z}$ calcd for $\mathrm{C}_{14} \mathrm{H}_{21} \mathrm{O}_{5}[\mathrm{M}+\mathrm{H}]^{+} 269.1389$, found 269.1380 .

Borohydride reduction of 9 . To a solution of $9(3.0 \mathrm{mg}, 0.0061 \mathrm{mmol})$ in anhydrous ethanol $(1 \mathrm{~mL})$ was added $\mathrm{NaBH}_{4}$ (a tip of spatula) at room temperature under stirring. After $1 \mathrm{~h}$ the mixture was diluted with ethanol (1 $\mathrm{mL}$ ) and $\mathrm{AcOH}$ (two drops) was added. The mixture was filtered and the solid was thoroughly washed with ethanol. The organic phase was dried $\left(\mathrm{Na}_{2} \mathrm{SO}_{4}\right)$ and taken to dryness under reduced pressure to give a colourless oil ( $3 \mathrm{mg}$ ). HPLC separation ( $250 \times 4.6 \mathrm{~mm}$ column; flow: $1.0 \mathrm{~mL} / \mathrm{min}$; hexane/EtOAc, 1:1) gave pure samples of 10 (0.3 mg, 10\%, $\left.t_{\mathrm{R}} 6.8 \mathrm{~min}\right)$ and 11 ( $\left.2.5 \mathrm{mg}, 75 \%, t_{\mathrm{R}} 35.5 \mathrm{~min}\right)$.

11. Oil;. IR (neat) $v_{\max }-3400(\mathrm{br}) \mathrm{cm}^{-1} ;{ }^{1} \mathrm{H}-\mathrm{NMR}\left(500 \mathrm{MHz}, \mathrm{CDCl}_{3}\right)$ selected values $\delta 4.11(1 \mathrm{H}, \mathrm{q}, J 9.1), 3.90(1 \mathrm{H}$, bd J 7.5), $3.78(1 \mathrm{H}), 3.72-3.80(2 \mathrm{H}, \mathrm{m}), 3.65(2 \mathrm{H}, \mathrm{t} J 5.4), 3.60(1 \mathrm{H}, \mathrm{dd} J$ 9.1, 4.8), $2.57(1 \mathrm{H}, \mathrm{ddd}, J 12.9,9.9,4.7)$, $2.48(1 \mathrm{H}, \mathrm{m}), 2.14(1 \mathrm{H}, \mathrm{bddd}, J 10.0,10.0,10.0), 2.00$ (1H, ddd, J 13.0, 9.5, 5.4), $1.42(1 \mathrm{H}, \mathrm{ddd}, J 12.6,12.6,4.8)$, $1.54,1.52,1.31,1.25,1.085,1.080,1.077$ (3H each, s's, 6xMe); ${ }^{13} \mathrm{C} \mathrm{NMR}\left(\mathrm{CDCl}_{3}\right.$, data from $\left.500 \mathrm{MHz} \mathrm{HMBC}\right) \delta$ 104.1, 86.1, 85.7, 84.7, 84.3, 81.9, 81.7, 80.0, 75.4, 72.7, 72.1, 63.6, 44.2, 37.2 (two carbons), 34.5, 31.2, 27.0 (two carbons), 26.7, 26.6, 26.3, 26.0, 25.0, 23.9, 21.4, 21.2; HRMS (ESI) $\mathrm{m} / \mathrm{z}$ calcd for $\mathrm{C}_{27} \mathrm{H}_{46} \mathrm{NaO}_{8}[\mathrm{M}+\mathrm{Na}]^{+}$ 521.3090, found 521.3075.

Oxidation of $\mathbf{2 7}$ with PCC/AcOH. Isolation of minor products 33-36. Penta-THF dibenzoate 27 was synthesized as previously described. ${ }^{23}$ Oxidation of $27(365 \mathrm{mg}, 0.50 \mathrm{mmol})$ with PCC as reported ${ }^{23}$ followed by filtration of the crude on a silica gel pad (eluent $\mathrm{CHCl}_{3}-\mathrm{MeOH}, 9: 1$ ) gave an oily product (350 mg). Separation by HPLC (250x10 mm column; flow: $2.5 \mathrm{~mL} / \mathrm{min}$; eluent: hexane-EtOAc, 75:25) gave still impure compounds 33-36 along with previously isolated compounds 28-32. Analytical HPLC ( 250 x $4.6 \mathrm{~mm}$ column; flow: $1.0 \mathrm{~mL} / \mathrm{min} ; 3$ $\mathrm{mg} /$ injection, hexane/EtOAc, 75:25) afforded lactones $\mathbf{3 3}\left(t_{\mathrm{R}} 18.0 \mathrm{~min}\right)$ and $\mathbf{3 4}\left(t_{\mathrm{R}} 13.0 \mathrm{~min}\right)$. Pure aldehydes 35 
(1.2 $\left.\mathrm{mg}, 1 \%, t_{\mathrm{R}} 13.8 \mathrm{~min}\right)$ and $36\left(1.2 \mathrm{mg}, 1 \%, t_{\mathrm{R}} 10.0 \mathrm{~min}\right)$ were obtained by HPLC on the same column by using hexane/EtOAc, 85:15. A further reversed-phase HPLC run $(250 \times 4.0 \mathrm{~mm}$ column; flow: $1.0 \mathrm{~mL} / \mathrm{min} ; 2$ $\mathrm{mg} /$ injection) was required to obtain pure $33\left(\mathrm{MeCN} / \mathrm{H}_{2} \mathrm{O}, 8: 2,5.0 \mathrm{mg}, 4 \%, t_{\mathrm{R}} 5.0 \mathrm{~min}\right)$ and $34\left(\mathrm{MeCN} / \mathrm{H}_{2} \mathrm{O}\right.$, $\left.85: 15,2.5 \mathrm{mg}, 2 \%, t_{\mathrm{R}} 4.5 \mathrm{~min}\right)$.

33 (major isomer). Oil; IR (neat): $v_{\max } 1775,1712,1288,713 \mathrm{~cm}^{-1} ;{ }^{1} \mathrm{H}-\mathrm{NMR}:\left(500 \mathrm{MHz}, \mathrm{CDCl}_{3}\right)$ selected values $\delta$ $7.96(2 \mathrm{H}, \mathrm{dd}, J$ 8.0, 1.0, phenyl orto protons), $7.52(\mathrm{H}$, dddd, J 7.4, 7.4, 1.2, 1.2, phenyl para proton), $7.42(2 \mathrm{H}$, bt, J 7.8, phenyl meta protons), $4.36(1 \mathrm{H}, \mathrm{dd}, J 7.9,6.1), 4.19(1 \mathrm{H}, \mathrm{dd}, J 7.0,7.0), 3.95(1 \mathrm{H}, \mathrm{dd}, J 9.2,6.1), 2.56$ $(1 \mathrm{H}, \mathrm{ddd}, J 17.7,10.1,6.3), 2.40(1 \mathrm{H}, \mathrm{ddd}, J 17.5,10.3,7.1), 2.32-2.24(1 \mathrm{H}, \mathrm{m}), 2.20-2.09$ (2H, overlapped multiplets), 2.08-2.0 (1H, m), 1.95-1.96 (2H, overlapped multiplets), 1.84-1.75 $(1 \mathrm{H}, \mathrm{m}), 1.61,1.59,1.20,1.19$ (3H each, s's, 4xMe); ${ }^{13} \mathrm{C}-\mathrm{NMR}\left(100 \mathrm{MHz}, \mathrm{CDCl}_{3}\right.$ ): $\delta 177.7,165.7,132.5,131.8,129.4$ (two carbons), 128.2 (two carbons), 84.4, 84.3, 83.8 (two carbons), 83.1, 83.0, 34.3, 32.3, 28.7, 27.6, 26.6, 23.1 (two carbons), 22.9, 22.6, 21.5; HRMS (ESI) $m / z$ calcd for $\mathrm{C}_{24} \mathrm{H}_{32} \mathrm{NaO}_{6}[\mathrm{M}+\mathrm{Na}]^{+} 439.2097$, found 439.2106.

34 (minor isomer). Oil; IR (neat): $v_{\max } 1776,1712,1288,714 \mathrm{~cm}^{-1}$; ${ }^{1} \mathrm{H}-\mathrm{NMR}:\left(400 \mathrm{MHz}, \mathrm{CDCl}_{3}\right)$ selected values $\delta$ $7.98(2 \mathrm{H}, \mathrm{bd}, J$ 8.2, phenyl orto protons), $7.52(\mathrm{H}, \mathrm{bt}, J \mathrm{~J} .0$, phenyl para proton), 7.41 (2H, bt, $J$ 7.5, phenyl meta protons), $4.38(1 \mathrm{H}, \mathrm{dd}, J$ 7.4, 4.8), $4.19(1 \mathrm{H}, \mathrm{dd}, J$ 9.3, 5.6), $3.85(1 \mathrm{H}, \mathrm{dd}, J 9.5,5.8), 2.65$ (1H, ddd, J 17.2, 9.8, 6.8), $2.45(1 \mathrm{H}, \mathrm{ddd}, J 17.1,10.6,6.3), 1.60$ (6H s, 2xMe), 1.19, 1.13 (3H each, s's, 2xMe); ${ }^{13} \mathrm{C}-\mathrm{NMR}(100 \mathrm{MHz}$, $\mathrm{CDCl}_{3}$ ): $\delta 177.7165 .7,132.4,129.4$ (two carbons), 128.1 (two carbons), 87.0, 85.9, 84.8, 83.6, 83.5, 83.3, 34.6, 34.1, 28.6, 26.9, 26.5, 24.5, 23.5, 22.9, 22.8, 21.6; HRMS (ESI) $\mathrm{m} / \mathrm{z}$ calcd for $\mathrm{C}_{24} \mathrm{H}_{32} \mathrm{NaO}_{6}[\mathrm{M}+\mathrm{Na}]^{+} 439.2097$, found 439.2100 .

35. Oil; IR (neat): $v_{\max } 1712,1288,712 \mathrm{~cm}^{-1} ;{ }^{1} \mathrm{H}-\mathrm{NMR}$ : $\left(500 \mathrm{MHz}, \mathrm{CDCl}_{3}\right)$ selected values $\delta 9.41(1 \mathrm{H}, \mathrm{d}, J 7.8)$, $7.98(2 \mathrm{H}, \mathrm{d}, J$ 8.0, phenyl orto protons), $7.52(\mathrm{H}, \mathrm{bt}, J$ 7.8, phenyl para proton), 7.40 (2H, bt, J 8.0, phenyl meta protons), $6.88(1 \mathrm{H}, \mathrm{d}, J 15.6), 6.17(1 \mathrm{H}, \mathrm{dd}, J 15.6,7.8), 4.21(1 \mathrm{H}, \mathrm{dd}, J 6.8,6.8), 4.06(1 \mathrm{H}, \mathrm{dd}, J 6.8,6.8), 1.62$, 1.61, 1.37, 1.22 (3H each, s's, 4xMe); HRMS (ESI) $m / z$ calcd for $\mathrm{C}_{23} \mathrm{H}_{30} \mathrm{NaO}_{5}[\mathrm{M}+\mathrm{Na}]^{+} 409.1991$, found 409.1996. 36. Oil; IR (neat): $v_{\max } 1712,1288,712 \mathrm{~cm}^{-1}$; ${ }^{1} \mathrm{H}-\mathrm{NMR}$ : $\left(500 \mathrm{MHz}, \mathrm{CDCl}_{3}\right.$ ) selected values $\delta \delta 9.58(1 \mathrm{H}, \mathrm{d}, J \mathrm{~J} .9$ ), $7.98(2 \mathrm{H}, \mathrm{d}, J$ 8.2, phenyl orto protons), $7.52(\mathrm{H}, \mathrm{bt}, J \mathrm{7.4}$, phenyl para proton), 7.41 (2H, bt, $J$ 8.0, phenyl meta protons), $6.84(1 \mathrm{H}, \mathrm{d}, J 15.6), 6.27(1 \mathrm{H}, \mathrm{dd}, J 15.6,7.9), 4.23(1 \mathrm{H}, \mathrm{dd}, J$ 9.6, 5.6), $3.94(1 \mathrm{H}, \mathrm{dd}, J 6.0,6.0), 1.61$ $(6 \mathrm{H}, \mathrm{s}, 2 \times \mathrm{Me}), 1.42,1.18$ (3H each, s's, 2xMe); HRMS (ESI) $\mathrm{m} / \mathrm{z}$ calcd for $\mathrm{C}_{23} \mathrm{H}_{30} \mathrm{NaO}_{5}[\mathrm{M}+\mathrm{Na}]^{+} 409.1991$, found 409.1990 .

\section{Acknowledgements}

The authors are grateful to Dr. Luisa Cuorvo and Dr. Brunella Pinto for their technical assistance.

\section{Supplementary Material}

Copies of ${ }^{1} \mathrm{H}$ and ${ }^{13} \mathrm{C}$ NMR spectra of compounds 9-14 and 33-36 are available.

\section{References}

1. Piancatelli, G.; Scettri, A.; D'Auria, M. Synthesis 1982, 245-258. 
https://doi.org/10.1055/s-1982-29766

2. Piancatelli, G.; Luzzio, F. A. In Encyclopedia of Ragents for Organic Synthesis, 2007, https://doi.org/10.1002/047084289X.rp288.pub2

3. Piccialli, V. Molecules 2014, 19, 6534-6582. https://doi.org/10.3390/molecules19056534

4. Piccialli, V.; Borbone, N.; Oliviero, G. Tetrahedron Lett. 2007, 48, 5131-5135. https://doi.org/10.1016/j.tetlet.2007.05.078

5. $\quad$ Piccialli, V. Tetrahedron Lett. 2000, 41, 3731-3733. https://doi.org/10.1016/S0040-4039(00)00476-7

6. Albarella, L.; Lasalvia, M.; Piccialli, V.; Sica, D. J. Chem. Soc. Perkin Trans. 2 1998, 3, 737-744. https://doi.org/10.1039/a700294g

7. Albarella, L.; Piccialli, V.; Smaldone, D.; Sica, D. J. Chem. Res. (S) 1996, 9, 400-401.

8. Albarella, L.; Giordano, F.; Lasalvia, M.; Piccialli, V.; Sica, D. Tetrahedron Lett. 1995, 36, 5267-5270.

9. Piccialli, V.; Sica, D.; Smaldone, D. Tetrahedron Lett. 1994, 35, 7093-7096. https://doi.org/10.1016/0040-4039(94)88234-7

10. Notaro, G.; Piccialli, V.; Sica, D.; Smaldone, D. Tetrahedron 1994, 50, 4835-4852. https://doi.org/10.1016/S0040-4020(01)85020-1

11. Piccialli, V.; Smaldone, D. M. A.; Sica, D. Tetrahedron 1993, 49, 4211-4228. https://doi.org/10.1016/S0040-4020(01)85739-2

12. Piccialli, V.; Zaccaria, S.; Centore, R.; Tuzi, A.; Borbone, N.; Oliviero, G. Molecules 2011, 16, 5362-5373. https://doi.org/10.3390/molecules16075362

13. Piccialli, V.; Zaccaria, S.; Borbone, N.; Oliviero, G.; D'Errico, S.; Hemminki, A.; Cerullo, V.; Romano, V.; Tuzi, A.; Centore, R. Tetrahedron 2010, 66, 9370-9378.

https://doi.org/10.1016/j.tet.2010.10.004

14. Piccialli, V.; Borbone, N.; Oliviero, G. Tetrahedron 2008, 64, 11185-11192.

https://doi.org/10.1016/i.tet.2008.09.052

15. Piccialli, V. Synthesis 2007, 17, 2585-2607. https://doi.org/10.1055/s-2007-983835

16. Piccialli, V.; Caserta, T.; Caruso, L.; Gomez-Paloma, L.; Bifulco, G. Tetrahedron 2006, 62, 10989-11007. https://doi.org/10.1016/i.tet.2006.08.038

17. Caserta, T.; Piccialli, V.; Gomez-Paloma, L.; Bifulco, G. Tetrahedron 2005, 61, 927-939. https://doi.org/10.1016/i.tet.2004.11.018

18. Piccialli, V.; Caserta, T. Tetrahedron Lett. 2004, 45, 303-308. https://doi.org/10.1016/j.tetlet.2003.10.173

19. Bifulco, G.; Caserta, T.; Gomez-Paloma, L.; Piccialli, V. Tetrahedron Lett. 2003, 44, 3429. https://doi.org/10.1016/S0040-4039(03)00566-5

20. Bifulco, G.; Caserta, T.; Gomez-Paloma, L.; Piccialli, V. Tetrahedron Lett. 2002, 43, 9265-9269. https://doi.org/10.1016/S0040-4039(02)02304-3

21. Piccialli, V.; Cavallo, N. Tetrahedron Lett. 2001, 42, 4695-4699. https://doi.org/10.1016/S0040-4039(01)00790-0

22. Piccialli, V.; Oliviero, G.; Borbone, N.; Tuzi, A.; Centore, R.; Hemminki, A.; Ugolini, M.; Cerullo, V. Org. Biomol. Chem., 2009, 7, 3036-3039.

https://doi.org/10.1039/b906872d 
23. Piccialli, V.; Zaccaria, S.; Oliviero, G.; D'Errico, S.; D'Atri, V.; Borbone, N. Eur. J. Org. Chem., 2012, 23, 4293-4305.

https://doi.org/10.1002/ejoc.201200069

24. Piccialli, V.; D' Errico, S.; Borbone, N.; Oliviero, G.; Centore, R.; Zaccaria, S. Eur. J. Org. Chem., 2013, 17811789.

https://doi.org/10.1002/ejoc.201201554

25. Roth, S.; Stark, C. B. W. Chem. Commun. 2008, 6411-6413.

https://doi.org/10.1039/b815135k

26. Ferraz, H. M. C.; Luongo, Jr., L. S. Org. Lett. 2003, 5, 1337-1339.

https://doi.org/10.1021/ol0342958

27. Ali, S. M.; Ramesh, K.; Borchardt, R. T. Tetrahedron Lett. 1990, 31, 1509-1512.

https://doi.org/10.1016/0040-4039(90)80002-4

28. Baskaran, S.; Chandrasekaran, S. Tetrahedron Lett. 1990, 31, 2775-2778.

https://doi.org/10.1016/S0040-4039(00)94696-3

29. Towne, T. B.; McDonald, F. E. J. Am. Chem. Soc. 1997, 119, 6022-6028.

https://doi.org/10.1021/ja962837t

30. Edmunds, A. J. F.; Trueb, W.; Oppolzer W.; Cowley, P. Tetrahedron 1997, 53, 2785-2802.

https://doi.org/10.1016/S0040-4020(97)00021-5

31. Yadav, J. S.; Reddy, M. S.; Prasad, A. R. Tetrahedron Lett., 2005, 46, 2133-2136. https://doi.org/10.1016/j.tetlet.2005.01.121

32. Yadav, J. S. ; Reddy, M. S.; Prasad, A. R. Tetrahedron Lett. 2006, 47, 4995-4998. https://doi.org/10.1016/j.tetlet.2006.05.116

33. Reddy, M. S.; Narender, M.; Rao, K. R. Tetrahedron 2007, 63, 11011-11015.

https://doi.org/10.1016/j.tet.2007.08.049

34. Kwart, H.; Ford, J. A. Jr.; Corey, G. C. J. Am Chem. Soc. 1962, 84, 1252-1256.

https://doi.org/10.1021/ja00866a038

35. Drees, M.; Strassner, T. J. Org. Chem. 2006, 71, 1755-1760.

https://doi.org/10.1021/jo051521d

36. Bakke, J. M.; Frøhaug, A. E. J. Phys. Org. Chem. 1996, 9, 507-513. https://doi.org/10.1002/(SICI)1099-1395(199607)9:7<507::AID-POC811>3.0.CO;2-L

37. Bakke, J. M.;Frøhaug, A. E. J. Phys. Org. Chem. 1996, 9, 310-318. https://doi.org/10.1002/(SICI)1099-1395(199606)9:6<310::AID-POC790>3.0.CO;2-E

38. Coudret, J. L.; Zoellner, S.; Ravoo, B. J.; Malara, L.; Hanisch, C.; Dorre, K.; de Meijere, A.; Waegell, B. Tetrahedron Lett. 1996, 37, 2425-2428 and references therein. https://doi.org/10.1016/0040-4039(96)00325-5

39. Bales, B. C.; Brown, P.; Dehestani, A.; Mayer, J. M. J. Am. Chem. Soc. 2005, 127, 2832-2833. https://doi.org/10.1021/ja044273w

40. Mayer, J. M.; Mader, E. A.; Roth, J. P.; Bryant, J. R.; Matsuo, T.; Dehestani, A.; Bales, B.; Watson, E. J.; Osako, T.; Valliant-Saunders, K.; Lam, W. H.; Hrovat, D. A.; Borden, W. T.; Davidson, E. R. J. Mol. Catal. A: Chem. 2006, 251, 24-33.

https://doi.org/10.1016/i.molcata.2006.02.010

41. Osako, T.; Watson, E. J.; Dehestani, A.; Bales, B. C.; Mayer, J. M. Angew. Chem., Int. Ed. 2006, 45, 74337436. 
https://doi.org/10.1002/anie.200602560

42. Tenaglia, A.; Terranova, E.; Waegell, B. J. Org. Chem. 1992, 57, 5523-5528. https://doi.org/10.1021/jo00046a040

43. Baskaran, S.; Islam, I.; Chandrasekaran, S. J. Org. Chem. 1990, 55, 891-895. https://doi.org/10.1021/jo00290a018

44. Fetizon, M.; Goulaouic, P.; Hanna, I. Tetrahedron Lett. 1988, 29, 6261-6264. https://doi.org/10.1016/S0040-4039(00)82320-5

45. Baskaran, S.; Islam, I.; Raghavan, M.; Chandrasekaran, S. Chem. Lett. 1987, 1175-1178. https://doi.org/10.1246/cl.1987.1175

46. Piancatelli, G.; Scettri, A.; D'Auria, M. Tetrahedron 1980, 36, 661-663. https://doi.org/10.1016/0040-4020(80)88010-0

47. Beihoffer, L. A.; Craven, R. A.; Knight, K. S.; Sisson, C. R.; Waddel, T. G. Transition Met. Chem. 2005, 30, 582-585. https://doi.org/10.1007/s11243-005-4049-8

48. McDonald, F. E.; Towne, T. B. J. Am. Chem. Soc: 1994, 116, 7921-7922. https://doi.org/10.1021/ja00096a069

49. Schlecht, M. F.; Kim, H.-J. J. Org. Chem. 1989, 54, 583-587. https://doi.org/10.1021/jo00264a015

50. Boyce, R.S.; Kennedy, R. M. Tetrahedron Lett. 1994, 35, 5133-5136. https://doi.org/10.1016/S0040-4039(00)77046-8 